\section{Plant Growth Regulators II}

\section{Methyl- and Methoxysubstituted Naphthylboronic Acids \\ SVEN-OLOV LAWESSON*}

\section{Department of Organic Chemistry, Chemical Institute, University of Uppsala, Sweden}

1- and 2-Naphthylmethylboronic acids have earlier been shown to be conspicuous anti-auxins ${ }^{1}$. As the aralkylboronic acids are very sensitive to atmospheric oxygen and difficult to handle, arylboronic acids hav $\theta$ also been included in the investi gation. Thus the writer has recently prepared a number of thiopheneboronic acids ${ }^{2}$. As he is not in a position to pursue these investigations for the time being, the data for some lately prepared naphthylboronic acid are given here.

Substituted phenylboronic acids have been investigated biologically by several authors ${ }^{3-7}$ and Professor B. Aberg is now testing the thiophene- and naphthylboronic acids. According to preliminary reports, they have about the same effect ${ }^{8}$ as those investigated by Torssell ?. The results will be published elsewhere.

The naphthyl boronic acids were prepared via the lithium reagents at a low tem-

* Present address: Department of Organic Chemistry, University of Chicago, Chicago 37, IIl. perature following usual procedures. The lithium reagents were obtained by lithium. halogen exchange reactions from the corresponding bromine compounds, except for 3-methoxy-2-naphthylboronic acid; in this case the lithium reagent was prepared by metalating 2-methoxynaphthalene by the method of Sunthankar and Gilman ${ }^{\circ}$.

Experimental. Reactions with lithium were performed under dry oxygen-free nitrogen in a standard assembly.

As a typical example we will describe the preparation of 2-methyl-1-naphthylboronic acid: $11 \mathrm{~g}$ of 1-bromo-2-methylnaphthalene in $75 \mathrm{ml}$ of absolute ether was cooled to $0^{\circ} \mathrm{C}$ and then treated with $50 \mathrm{ml}$ of $1 \mathrm{M}$ butyl. lithium in ether. After stirring for $15 \mathrm{~min}$ the lithium reagent was slowly added with stirring to $20 \mathrm{~g}$ of tributyl borate in dry ether, cooled to $-70^{\circ} \mathrm{C}$. The stirring was continued for $4 \mathrm{~h}$ and then the reaction mixture was treated with 1 M hydrochloric acid, the ether layer separated and the aqueous phase extracted with ether. The combined ether layers were extracted with sodium hydroxide. The alkaline solution was acidified with hydrochloric acid, precipitating the acid as a white powder. After recrystallisation from water-ethanol and drying in air the acid was obtained as small, white needles. M. p. $125-127^{\circ} \mathrm{C}$. Weight 3.8 g. Yield $41 \%$.

The data for this and the other boronic acids are tabulated in Table 1.

The author is indebted to Professor B. Åberg for private communications. A grant from the Swedish Natural Science Research Council is gratefully acknowledged.

Table 1. Preparation of substituted naphthylboronic acids via the lithium reagent.

\begin{tabular}{|c|c|c|c|c|}
\hline & & \multicolumn{2}{|c|}{ Boron } \\
\cline { 3 - 5 } & $\begin{array}{c}\text { M. p. } \\
{ }^{\circ} \mathrm{C}\end{array}$ & $\begin{array}{c}\text { Yield } \\
{ }^{\circ} \mathrm{C}\end{array}$ & $\begin{array}{c}\text { Calc. } \\
\%\end{array}$ & $\begin{array}{c}\text { Found } \\
\%\end{array}$ \\
\hline 2-Methyl-1-naphthyl- & $125-127$ & 41 & 5.83 & 5.85 \\
4-Methyl-1-naphthyl- & $205-207$ & 54 & 5.83 & 5.87 \\
2-Methoxy-l-naphthyl- & $143-145$ & 50 & 5.36 & 5.35 \\
3-Methoxy-2-naphthyl- & $153-155$ & 39 & 5.36 & 5.39 \\
\hline
\end{tabular}


1. Lawesson, S.-O. Arkiv Kemi 10 (1956) 171.

2. Lawesson, S.-O. Arkiv Kemi 11 (1957) 387.

3. Caujolle, F. and Bergal, G. Compt. rend. 228 (1949) 1516.

4. Caujolle, F. and Bergal, G. Ibid 230 (1950) 1101.

5. Caujolle, F. and Bergal, G. Ibid. 231 (1950) 1550.
6. Caujolle, F. and Bergal, G. Ibid 232 (1951) 109.

7. Torssell, K. Physiol. Plantarum 9 (1956) 652.

8. Aberg, B. Private communication.

9. Sunthankar, S. V. and Gilman, H. J. Org. Chem. 16 (1950) 8.

Received August 16, 1957. 